\title{
Processing and consumer acceptance of fruit leather from the unfertilised floral parts of jackfruit
}

\begin{abstract}
A fruit leather was developed from the unfertilised floral parts of jackfruit. The characteristics of the leather were as follows: moisture $12.26 \%$, fat $0.26 \%$, protein $2.85 \%$, crude fibre $6.27 \%$, ash $0.87 \%, \mathrm{pH} 4-8$, titratable acidity 0.0005 meq $\mathrm{NaOH}$ g-1, vitamin $\mathrm{C}$ $0.023 \mathrm{mg}$ ascorbic acid per $100 \mathrm{~g}$, caloric value $440 \mathrm{kcal}$ per $100 \mathrm{~g}$ and water activity 0.6 . The colour was bright yellow. Microbial count of the leather was low throughout the storage period. The fruit leather was most stable when packaged in laminated aluminium foil (LAF) during storage. Sensory evaluation showed that samples were acceptable by the panelists. A market survey showed that the fruit leather was slightly better accepted by the consumer at large than laboratory sensory panelists, especially by male respondents and from ethnic Indians. However, more work is needed to further improve the new fruit leather.
\end{abstract}

Keyword: Fruit leather; Jackfruit; LAF; Market survey; Respondents; Unfertilised floral parts 